\title{
Genetic etiologies of central precocious puberty
}

\section{Hae Sang Lee}

Department of Pediatrics, Ajou University Hospital, Ajou University School of Medicine, Suwon, Korea

Received: August 6, 2021

Revised: August 25, 2021

Accepted: August 27, 2021

Corresponding author:

Hae Sang Lee

Department of Pediatrics, Ajou University Hospital, Ajou University School of Medicine, 164 Worldcup-ro, Yeongtonggu, Suwon 16499, Korea

Tel: +82-31-219-5166

E-mail: seaon98@naver.com

\begin{abstract}
Pubertal onset is a complex process, which is influenced by genetic and environmental factors, such as obesity and endocrine-disrupting chemicals. In addition, the timing of normal puberty varies between individuals and is a highly polygenic trait with both rare and common variants. Central precocious puberty (CPP) is defined as the early activation of the hypothalamic-pituitary-gonadal axis. Genetic factors are suggested to account for $50 \%$ to $80 \%$ of the variation in puberty initiation, as indicated by the greater concordance of pubertal timing observed in monozygotic twins than in dizygotic twins. Although genetic factors play a crucial role in CPP development, only few associated genes have been identified. To date, four monogenic genes have been identified: KISS1, $K I S S 1 R, M K R N 3$, and DLK1. Moreover, mutation prevalence in these genes varies considerably depending on the ethnicity of patients with CPP. This article reviews the current knowledge on the normal pubertal timing and physiology and discusses the CPP-causing genes.
\end{abstract}

Keywords: Etiology; Puberty; Puberty, precocious
This is an Open Access article distributed under the terms of the Creative Commons Attribution Non-Commercial License (https:// creativecommons.org/licenses/ by-nc/4.0/).

\section{INTRODUCTION}

Puberty is considered to be the most characteristic change in the process of development from birth to adulthood, and the period of puberty is often called "an age of storm and stress." During this period, secondary sexual characteristics are expressed, rapid body growth is achieved, fertilization ability is completed, and many social and psychological changes occur [1]. To date, the factors that trigger puberty are among the mysteries that remain scientifically unsolved.

The beginning of puberty is a complex process which is influenced by genetic and environmental factors, such as obesity and endocrine-disrupting chemicals [2-5]. Metabolic hormones, including leptin and ghrelin, can affect pubertal timing [6]. Recent westernized eating habits and the increase in obesity are thought to be related to the increased incidence of precocious puberty [7]. As the degree of obesity increases, the age of menarche tends to be earlier, and the incidence of precocious puberty in obese children is higher than in children of normal weight [8]. Therefore, alterations in an individual's nutritional status may affect pubertal onset. Genetic factors are considered play a crucial role in pubertal onset. The fact that this onset differs between races, and the similarity of menarche between mothers and daughters, further 
supports the notion that genetic variations affect pubertal onset. Greater concordance of pubertal timing has been found in monozygotic twins than in dizygotic twins [9]. Genetic factors are suggested to account for $50 \%$ to $80 \%$ of the variation in the initiation of puberty $[10,11]$. Despite the strong heritability of pubertal timing, our understanding of the underlying genetics remains limited. In this paper, we review the current knowledge on the normal pubertal timing and physiology of puberty, and discuss the central precocious puberty (CPP)-causing genes.

\section{PHYSIOLOGY OF PUBERTY}

Sexual development, including breast development or testicular enlargement, is initiated through hypothalamic-pituitary-gonadal (HPG) axis reactivation, after initial activation during the fetal and early postnatal periods [12]. However, before pubertal onset, the negative feedback mechanism acts excessively, and gonadotropins, such as luteinizing hormone (LH) and follicle stimulating hormone (FSH), do not increase despite the low serum sex hormone concentration. Neurons that produce gonadotropin-releasing hormones $(\mathrm{GnRH})$ are suppressed, and inhibitory neurotransmitters, such as opioids, gamma-aminobutyric acid, and melatonin are involved [13].

The HPG axis is reactivated at pubertal onset with the reemergence of pulsatile $\mathrm{GnRH}$ release, likely owing to increase in activators, such as kisspeptin signals, which direct $\mathrm{GnRH}$ neurons to control pulsatile GnRH release. This occurs via elevation of LH and FSH levels through the pituitary, with downstream activation of sex steroids, including estrogen and testosterone [14]. When puberty begins, LH secretion is initiated at night, which gradually increases in amount and frequency, developing the gonads and promoting sex hormone secretion. During mid-puberty, the pulsatile LH secretion occurs during the day, and the secretion cycle is 90 to 120 minutes [15].

Kisspeptin, a peptide hormone expressed in the hypothalamus, is essential for pubertal onset and progression in mammals [16]. Kisspeptin is encoded by the KISS1 gene that binds to the KISS1 receptor (KISS1R). The KISS1 gene was first discovered in 1996 and has since been mapped to the long arm of chromosome 1q32. The gene consists of three exons, of which two partially translated exons (exons 2 and 3 ) give rise to a 145 amino acid precursor peptide [17]. Stimulant neuromodulators contain neurokinin $B$ (NKB), which is encoded by the tachykinin 3 (TAC3) gene. Mutations involving dysfunc- tion of genes encoding TAC3 genes (coding NKB) or TACR3 genes (NKB receptor coding) have contributed to the development of hypogonadism and delayed puberty. As a result, NKB stimulates GnRH release through Kiss1 neurons [18]. Kisspeptin/NKB neurons in arcuate nucleus co-express a third peptide, dynorphin (Dyn). This endogenous opioid peptide inhibits kisspeptin secretion. In animal studies, the administration of Dyn receptor antagonists leads to early pubertal onset [19]. Given the interconnection between these neuromodulators, such as NKB, Dyn, and kisspeptin, called KNDy, the pulsatile $\mathrm{GnRH}$ secretion is based on coordinated activity in the KNDy neuronal network, in which NKB stimulates kisspeptin and Dyn exerts an inhibitory action [20].

\section{NORMAL PUBERTAL TIMING}

Puberty generally begins between the ages of 8 and 13 in girls and between 9 and 14 in boys; however, the timing varies between individuals [21]. The first pubertal change in boys is testicle enlargement. In general, if the length and volume of the testicles is greater than $2.5 \mathrm{~cm}$ and $4 \mathrm{cc}$, respectively, puberty is considered to have begun. Following this, the scrotum becomes more scrotal, pubic hair develops as the penis develops, and axillary hair commonly appears mid-puberty. Rapid pubertal growth in boys, unlike girls, occurs in stages IV to $V$ of the Tanner stages and occurs about 2 years later than in girls. Moreover, breast tissue development is the first sign of puberty in girls. Then, pubic hair develops within 6 to 12 months, and rapid pubertal growth occurs in Tanner stage II or III, followed by menarche [13]. Menarche, defined as the first menstruation, is a milestone during pubertal development in girls, as it represents the onset of female reproductive capacity. Menarche is a late event during puberty and typically occurs 2 to 2.5 years after pubertal onset. The average age at menarche decreased from 17 years in 1840 to approximately 12 years in 2000 in the majority of developed countries, and has remained stable over the last few decades [22]. Age at menarche varies across countries, generations, and races. In Korea, mean age at menarche decreased from 16.90 years for women born between 1920 and 1925 to 13.79 years for those born between 1980 and 1985, according to the Korean National Health and Nutrition Survey [23].

\section{CENTRAL PRECOCIOUS PUBERTY}

CPP, a disease with a striking female predominance, results 
from early HPG axis activation, and affected children show pubertal levels of gonadotropins and progressive sexual development, such as breast development and testicular enlargement, before ages 8 and 9 in girls and boys, respectively [21]. In a recent Korean epidemiologic study, the overall CPP incidence was 122.8 per 100,000 children, with CPP incidence being greater in girls (262.8) than in boys (7.0). In Western countries, the estimated CPP prevalence is approximately 1 in 5,000 to $10,000[13,24,25]$.

\section{GENETIC ETIOLOGIES OF CPP}

\section{KISS1 and KISS1R}

Gain-of-function mutations in the genes encoding kisspeptin and its receptor, KISS1 and KISSIR (previously G protein coupled receptor 54 [GPR54]) have been suggested as causes of CPP (Table 1) [26,27]. First, loss-of-function mutations in the $K I S S 1 R$ gene could lead to idiopathic hypogonadotropic hypogonadism in 2003 [28,29]. Since 2003, further KISS1R mutations have been reported to cause idiopathic hypogonadotropic hypogonadism [30-32]. The first case of CPP with an identifiable KISSIR mutation was reported in 2008 [27]. A Brazilian girl exhibited breast development shortly after birth, with progression. At age 8 , she had reached Tanner stage IV breast development, accelerated growth, and advanced bone age. A heterozygous gain-of-function mutation (p.Arg386Pro) in KISSIR was detected. Familial evaluation was not performed because the patient was adopted. In func- tional analysis, this mutation resulted in prolonged activation of intracellular KISSIR downstream signaling in response to kisspeptin stimulation.

Two years after reports of KISSIR gene mutations in a patient with CPP, gain-of-function mutations in the KISS1 gene were discovered in three Brazilian children [33]. The boy with the KISS1 gene mutation (p.Pro74Ser) exhibited secondary sexual development as early as 17 months of age. This mutation was inherited from his unaffected mother and grandmother. In vitro, the heterozygous mutant (p.Pro74Ser) was shown to decrease degradation, so this mutant may sustain increased protein bioavailability. Additionally, a homozygous mutation in the KISS1 gene (p.His90Asp) in two unrelated girls with sporadic CPP was detected. This mutant was undetected in controls with normal pubertal progression. The affected girls exhibited breast development at 6 and 5.5 years of age. However, the p.His90Asp variant did not show increased activity or resistance to degradation in vitro.

The important function of the KISSI/KISS1R system in the pubertal process makes it necessary to investigate the mutations and polymorphisms in the KISS1 gene and their association with CPP as well as the KISSIR gene. However, only small groups have described mutations in KISS1 and KISSIR $[34,35]$. In Korea, researchers attempted to identify mutations in KISS1 and KISSIR in Korean girls with CPP; however, definitive mutations were not found [26,36,37]. To date, KISS1 and KISS1R mutations are rare causes of monogenic CPP. Further replication studies are required to validate these findings.

Table 1. Known pathogenic genes associated with central precocious puberty

\begin{tabular}{|c|c|c|c|c|c|}
\hline Gene & Location & Protein & Function & Type of mutation & Other information \\
\hline KISS1 & $1 q 32$ & Kisspeptin & Binds to KISS1 receptor & $\begin{array}{l}\text { Gain-of-function } \\
\text { missense }\end{array}$ & \\
\hline KISS1R & $19 \mathrm{p} 13.3$ & KISS1R & $\begin{array}{l}\text { Increased GnRH } \\
\text { pulsatility }\end{array}$ & $\begin{array}{l}\text { Gain-of-function } \\
\text { missense }\end{array}$ & \\
\hline \multirow[t]{5}{*}{ MKRN3 } & $15 q 11-q 13$ & MKRN3 & $\begin{array}{l}\text { Ubiquitinylation, cell } \\
\text { signaling }\end{array}$ & Loss-of-function & \\
\hline & & & & Stop codon & \\
\hline & & & & Frameshift & \\
\hline & & & & Missense & \\
\hline & & & & Deletion & \\
\hline \multirow[t]{3}{*}{$D L K 1$} & $14 q 32$ & $\begin{array}{l}\text { Delta-like } \\
\text { homolog } 1\end{array}$ & $\begin{array}{l}\text { Pituitary cell } \\
\text { differentiation }\end{array}$ & Loss-of-function & $\begin{array}{l}\text { Metabolic abnormalities (obesity, type } 2 \\
\text { diabetes, hyperlipidemia) }\end{array}$ \\
\hline & & & & Deletion & \\
\hline & & & & Frameshift & \\
\hline
\end{tabular}

MKRN3, makorin ring finger protein 3; GnRH, gonadotropin-releasing hormone; DLK1, delta-like homolog 1. 


\section{MKRN3}

With the advancements in genetic evaluation techniques, such as next-generation sequencing, the genetics of CPP has been extensively investigated. In 2003, Abreu et al. [38] reported that makorin ring finger protein 3 (MKRN3) was detected in familial CPP through whole exome sequencing. Several variants predicted to be deleterious, such as frameshift, nonsense, and missense mutations in MKRN3, were found in five unrelated families. Since the initial report in 2013, MKRN3 gene mutations have been reported in various ethnicities and countries [39,40]. MKRN3 mutations are now the most commonly known genetic factors in CPP. In a recent review, 115 patients with CPP carrying MKRN3 mutations were reported to harbor 48 different genetic variants [39]. The prevalence of MKRN3 mutations was $33 \%$ to $46 \%$ in familial and $0.4 \%$ to $3.8 \%$ in sporadic CPP [40]. Furthermore, the frequency of MKRN3 mutations appears to be higher among boys than among girls with CPP [41].

In Korea, Lee et al. [42] investigated MKRN3 gene variants in 260 Korean girls with CPP. In this study, only one novel nonsense mutation (p.Gln281*) was detected in 260 girls with idiopathic CPP. The proband revealed a heterozygous $\mathrm{C}>\mathrm{T}$ nucleotide change $(\mathrm{c} .841 \mathrm{C}>\mathrm{T}$ ), which predicted a truncated protein due to a premature stop codon in the MKRN3 gene. In this girl, basal and peak stimulated LH levels were relatively high, and there was no CNS abnormality. Her father could not recall the exact onset age of puberty, he just remembered that she was more mature than her peers. Her brother had the same nonsense mutation and advanced bone age. Thus, according to past history and clinical findings, her father and brother might have undergone precocious puberty, although exact pubertal onset is unknown. The MKRN3 mutation was identified in only one out of 260 with CPP in Korea, which is significantly lower compared to Western countries that reported CPP to be associated with MKRN3 gene mutations. These findings highlight the existence of genetic heterogeneity across ethnic groups and the need for further studies.

Genotype-phenotype correlation studies have reported that patients harboring MKRN3 mutations appear to be similar to CPP patients without MKRN3 mutations [40,43]. In 71 patients harboring MKRN3 mutations, the average age at which secondary sexual characteristics appeared was $6.2 \pm$ 1.2 years in girls and $7.1 \pm 1.5$ years in boys [43]. Interestingly, subjects with severe MKRN3 mutations, including stop codon and frameshift, had more advanced bone age than subjects with missense mutations $(2.3 \pm 1.6$ years vs. $1.6 \pm 1.4$ years). In addition, MRKN3 mutations do not cause additional clinical phenotypes, such as obesity, except for early pubertal onset.

MKRN3 is a maternally imprinted gene; therefore, only the paternal allele is expressed. The exact mechanisms by which MKRN3 mutations affect HPG axis activation remain unclear. The MKRN3 gene was detected on chromosome 15q11.2, which is a critical region and has been shown to play a role in Prader-Willi syndrome (PWS) [44]. Delayed and incomplete puberty has been documented in most PWS patients; therefore, MKRN3 deletion may not necessarily be the cause [45]. Interestingly, there have been a few reports on CPP in PWS patients [46,47]. MKRN3 consists of three zinc finger domains (C3H), one zinc RING finger domain (C3HC4), and one MKRN3specific Cys-His domain (CH), and is expressed ubiquitously in the human hypothalamus [48]. Based on its structure, MKRN3 is predicted to function as a putative E3-ubiquitin ligase, and potentially affects gene expression, targeted protein degradation, and protein function modulation via its E3 ligase activity [39]. It can be assumed that the MKRN3 gene has an inhibitory effect on pubertal onset. In Denmark, serum MKRN3 concentrations decreased before pubertal onset, and circulating MKRN3 levels were negatively correlated with $\mathrm{LH}$ and FSH levels in healthy girls [49]. These findings support the hypothesis that the MKRN3 gene may have an inhibitory effect on reproductive endocrine activity.

\section{DLK1}

In 2017, Dauber et al. [50] performed whole genome sequencing in a Brazilian family with five CPP females, and found a paternally inherited large deletion of the delta-like homolog 1 (DLK1) gene. A complex defect DLK1 gene, approximately $14 \mathrm{~kb}$ heterozygous deletion in the first exon, including the translational start site, and a 269-base pair duplication of intron 3 was identified. Four affected sisters were described with the onset of secondary sexual development between the ages of 4.6 and 5.9 years. Similar to MKRN3 gene inheritance, $D L K 1$ is a maternally imprinted, paternally expressed gene [51]. Recently, Gomes et al. [52] investigated 60 female patients with a history of CPP or early menarche for DLK1 mutations. Three frameshift mutations with paternal expression in five female patients from three unrelated families were identified. Interestingly, patients harboring DLK1 mutations observed more metabolic abnormalities, including glucose intolerance, type 2 diabetes mellitus, and obesity than CPP patients not harboring DLK1 mutations [52]. Moreover, a rare heterozygous deletion in the splice site junction of $D L K 1$ 
was identified in a Spanish girl with sporadic CPP. Her pubertal signs first began at the age of 5.7 [53].

Lee et al. [54] performed a genetic association study among Korean girls with CPP. The authors identified five polymorphisms via Sanger sequencing of $D L K 1$. However, no high-impact mutations, such as frameshift or nonsense variants, were identified. In addition, Chen et al. [55] reported that no pathogenic DLK1 mutations were identified in 19 Chinese girls with CPP and early puberty. Therefore, DLK1 mutations may not be a frequent cause of CPP.

DLK1 is a noncanonical ligand that binds to the Notch receptors [56]. The Delta-Notch signaling pathway is highly conserved in all species, and DLK1 is expressed in the normal pituitary gland and hypothalamus [56-58]. Further studies are needed to elucidate the reproductive function of $D L K 1$.

In addition, both MKRN3 and DLK1 are imprinted genes. Imprinted genes whose expression is restricted to a single parental allele are important for growth and development. Therefore, imprinting disturbances due to epigenetics have been reported in several human disorders including PWS, Beckwith-Wiedemann syndrome, and Russell-Silver syndrome [59]. The mechanism by which imprinting genes influences pubertal expression remains unknown. Kotler and Haig [60] suggested that maternally expressed imprinted genes favor fast childhood development, while paternally expressed genes tend to delay growth. Also, patients with Temple syndrome show clearly CPP with accelerated bone age. Temple syndrome is the result of uniparental maternal expression of genes in chromosome 14 [61]. These findings provide a new perspective on the development of puberty.

\section{OTHER CANDIDATE GENES}

In the past decade, genetic loci that affect pubertal timing in normal girls have been identified using genome-wide association studies (GWASs) [62]. The majority of GWASs have used recalled age at menarche as it is the most frequent initial clinical hallmark of female pubertal onset. Several genes or loci, including lin-28 homolog B (LIN28B), tachykinin receptor 3 (TACR3), estrogen receptor 1 (ESR1), and 9q31.2, were associated with age at menarche in such GWASs [63-65]. Moreover, genes biologically linked to gonadotropin signaling, such as GNRH1, LH receptor, and FSH receptor, or encoding steroidogenesis enzymes, including CYP19A1 and CYP17, may affect pubertal onset and progression; however, these pathogenic mutations have not been revealed in patients with CPP [66-69].

\section{CONCLUSION}

The regulation of puberty is multifactorial and is known to be associated with various genetic and environmental factors. However, the pathophysiology of pubertal onset is not entirely understood yet. Many research groups have sought to identify the genetic causes of CPP; but, to date, only four monogenic genes have been identified: KISS1, KISS1R, MKRN3, and $D L K 1$. Moreover, mutation prevalence in MKRN3 or DLK1 in CPP varies considerably depending on ethnicity $[42,70]$. These findings suggest the existence of genetic heterogeneity across ethnic groups and highlight the requirement for further genetic studies.

\section{CONFLICTS OF INTEREST}

No potential conflict of interest relevant to this article was reported.

\section{ORCID}

Hae Sang Lee https://orcid.org/0000-0002-9684-4042

\section{AUTHOR CONTRIBUTIONS}

Conception or design: HSL.

Acquisition, analysis, or interpretation of data: HSL.

Drafting the work or revising: HSL.

Final approval of the manuscript: HSL.

\section{REFERENCES}

1. Smith CE, Biro FM. Pubertal development: what's normal/what's not. Clin Obstet Gynecol 2020;63:491-503.

2. Roa J, Barroso A, Ruiz-Pino F, Vazquez MJ, Seoane-Collazo $P$, Martinez-Sanchez N, et al. Metabolic regulation of female puberty via hypothalamic AMPK-kisspeptin signaling. Proc Natl Acad Sci U S A 2018;115:E10758-67.

3. Herbison AE. Genetics of puberty. Horm Res 2007;68 Suppl 5:75-9.

4. Lee JE, Jung HW, Lee YJ, Lee YA. Early-life exposure to endocrine-disrupting chemicals and pubertal development in girls. Ann Pediatr Endocrinol Metab 2019;24:78-91.

5. Heo S, Lee YS, Yu J. Basal serum luteinizing hormone value as the screening biomarker in female central precocious puberty. Ann Pediatr Endocrinol Metab 2019;24: 164-71. 
6. Huang A, Roth CL. The link between obesity and puberty: what is new? Curr Opin Pediatr 2021;33:449-57.

7. Lim KI, Lee HS, Hwang JS. Changes in body mass index in boys with central precocious puberty over 2 years of gonadotropin-releasing hormone agonist therapy. Ann Pediatr Endocrinol Metab 2020;25:169-73.

8. Burt Solorzano CM, McCartney CR. Obesity and the pubertal transition in girls and boys. Reproduction 2010;140: 399-410.

9. Fischbein S. Intra-pair similarity in physical growth of monozygotic and of dizygotic twins during puberty. Ann Hum Biol 1977;4:417-30.

10. Dvornyk V, Waqar-ul-Haq. Genetics of age at menarche: a systematic review. Hum Reprod Update 2012;18:198-210.

11. Palmert MR, Hirschhorn JN. Genetic approaches to stature, pubertal timing, and other complex traits. Mol Genet Metab 2003;80:1-10.

12. Renault $C H$, Aksglaede L, Wojdemann $D$, Hansen $A B$, Jensen RB, Juul A. Minipuberty of human infancy: a window of opportunity to evaluate hypogonadism and differences of sex development? Ann Pediatr Endocrinol Metab 2020;25:84-91.

13. Abreu AP, Kaiser UB. Pubertal development and regulation. Lancet Diabetes Endocrinol 2016;4:254-64.

14. Spaziani M, Tarantino C, Tahani N, Gianfrilli D, Sbardella E, Lenzi A, et al. Hypothalamo-pituitary axis and puberty. Mol Cell Endocrinol 2021;520:111094.

15. Witchel SF, Plant TM. Neurobiology of puberty and its disorders. Handb Clin Neurol 2021;181:463-96.

16. Skorupskaite K, George JT, Anderson RA. The kisspeptin-GnRH pathway in human reproductive health and disease. Hum Reprod Update 2014;20:485-500.

17. West A, Vojta PJ, Welch DR, Weissman BE. Chromosome localization and genomic structure of the KiSS-1 metastasis suppressor gene (KISS1). Genomics 1998;54:145-8.

18. Bianco SD, Kaiser UB. The genetic and molecular basis of idiopathic hypogonadotropic hypogonadism. Nat Rev Endocrinol 2009;5:569-76.

19. Nakahara T, Uenoyama Y, Iwase A, Oishi S, Nakamura S, Minabe S, et al. Chronic peripheral administration of kappa-opioid receptor antagonist advances puberty onset associated with acceleration of pulsatile luteinizing hormone secretion in female rats. J Reprod Dev 2013;59:47984.

20. Grumbach MM. The neuroendocrinology of human puberty revisited. Horm Res. 2002;57 Suppl 2:2-14.

21. Carel JC, Leger J. Clinical practice. Precocious puberty. N
Engl J Med 2008;358:2366-77.

22. Papadimitriou A. The evolution of the age at menarche from prehistorical to modern times. J Pediatr Adolesc Gynecol 2016;29:527-30.

23. Cho GJ, Park HT, Shin JH, Hur JY, Kim YT, Kim SH, et al. Age at menarche in a Korean population: secular trends and influencing factors. Eur J Pediatr 2010;169:89-94.

24. Soriano-Guillen L, Corripio R, Labarta JI, Canete R, Castro-Feijoo L, Espino R, et al. Central precocious puberty in children living in Spain: incidence, prevalence, and influence of adoption and immigration. J Clin Endocrinol Metab 2010;95:4305-13.

25. Teilmann G, Pedersen CB, Jensen TK, Skakkebaek NE, Juul A. Prevalence and incidence of precocious pubertal development in Denmark: an epidemiologic study based on national registries. Pediatrics 2005;116:1323-8.

26. Ko JM, Lee HS, Hwang JS. KISS1 gene analysis in Korean girls with central precocious puberty: a polymorphism, p.P110T, suggested to exert a protective effect. Endocr J 2010;57:701-9.

27. Teles MG, Bianco SD, Brito VN, Trarbach EB, Kuohung W, Xu S, et al. A GPR54-activating mutation in a patient with central precocious puberty. N Engl J Med 2008;358:70915.

28. de Roux N, Genin E, Carel JC, Matsuda F, Chaussain JL, Milgrom E. Hypogonadotropic hypogonadism due to loss of function of the KiSS1-derived peptide receptor GPR54. Proc Natl Acad Sci U S A 2003;100:10972-6.

29. Seminara SB, Messager S, Chatzidaki EE, Thresher RR, Acierno JS Jr, Shagoury JK, et al. The GPR54 gene as a regulator of puberty. N Engl J Med 2003;349:1614-27.

30. Lanfranco F, Gromoll J, von Eckardstein S, Herding EM, Nieschlag E, Simoni M. Role of sequence variations of the $\mathrm{GnRH}$ receptor and G protein-coupled receptor 54 gene in male idiopathic hypogonadotropic hypogonadism. Eur J Endocrinol 2005;153:845-52.

31. Semple RK, Achermann JC, Ellery J, Farooqi IS, Karet FE, Stanhope RG, et al. Two novel missense mutations in $\mathrm{g}$ protein-coupled receptor 54 in a patient with hypogonadotropic hypogonadism. J Clin Endocrinol Metab 2005;90: 1849-55.

32. Tenenbaum-Rakover Y, Commenges-Ducos M, lovane A, Aumas C, Admoni O, de Roux N. Neuroendocrine phenotype analysis in five patients with isolated hypogonadotropic hypogonadism due to a L102P inactivating mutation of GPR54. J Clin Endocrinol Metab 2007;92:1137-44.

33. Silveira LG, Noel SD, Silveira-Neto AP, Abreu AP, Brito VN, 
Santos MG, et al. Mutations of the KISS1 gene in disorders of puberty. J Clin Endocrinol Metab 2010;95:2276-80.

34. Luan X, Zhou Y, Wang W, Yu H, Li P, Gan X, et al. Association study of the polymorphisms in the KISS1 gene with central precocious puberty in Chinese girls. Eur J Endocrinol 2007;157:113-8.

35. Silveira LF, Brito VN, Costa EMF, Trarbach EB, Teles M, Mendonca BB, et al. A novel missense mutation of KISS1 gene in a boy with idiopathic gonadotropin-dependent precocious puberty. 88th Scientific Sessions of the Endocrine Society; 2006 Jun 24-27; Boston, MA. Endocrine society.

36. Rhie YJ, Lee KH, Ko JM, Lee WJ, Kim JH, Kim HS. KISS1 gene polymorphisms in Korean girls with central precocious puberty. J Korean Med Sci 2014;29:1120-5.

37. Ko JM, Lee HS, Lee HS, Hwang JS. Genetic variations of GNRH1, GNRHR and GPR54 genes in Korean girls with central precocious puberty. J Korean Soc Pediatr Endocrinol 2011;16:38-45.

38. Abreu AP, Dauber A, Macedo DB, Noel SD, Brito VN, Gill JC, et al. Central precocious puberty caused by mutations in the imprinted gene MKRN3. N Engl J Med 2013;368:246775.

39. Maione L, Naule L, Kaiser UB. Makorin RING finger protein 3 and central precocious puberty. Curr Opin Endocr Metab Res 2020;14:152-9.

40. Valadares LP, Meireles CG, De Toledo IP, Santarem de OIiveira R, Goncalves de Castro LC, Abreu AP, et al. MKRN3 mutations in central precocious puberty: a systematic review and meta-analysis. J Endocr Soc 2019;3:979-95.

41. Bessa DS, Macedo DB, Brito VN, Franca MM, Montenegro LR, Cunha-Silva M, et al. High frequency of MKRN3 mutations in male central precocious puberty previously classified as idiopathic. Neuroendocrinology 2017;105:17-25.

42. Lee HS, Jin HS, Shim YS, Jeong HR, Kwon E, Choi V, et al. Low frequency of MKRN3 mutations in central precocious puberty among Korean girls. Horm Metab Res 2016;48: 118-22.

43. Seraphim CE, Canton APM, Montenegro L, Piovesan MR, Macedo DB, Cunha M, et al. Genotype-phenotype correlations in central precocious puberty caused by MKRN3 mutations. J Clin Endocrinol Metab 2021;106:1041-50.

44. Cassidy SB, Driscoll DJ. Prader-Willi syndrome. Eur J Hum Genet 2009;17:3-13.

45. Kanber D, Giltay J, Wieczorek D, Zogel C, Hochstenbach R, Caliebe A, et al. A paternal deletion of MKRN3, MAGEL2 and NDN does not result in Prader-Willi syndrome. Eur J
Hum Genet 2009;17:582-90.

46. Lee HS, Hwang JS. Central precocious puberty in a girl with Prader-Willi syndrome. J Pediatr Endocrinol Metab 2013;26:1201-4.

47. Linnemann K, Schroder C, Mix M, Kruger G, Fusch C. Prader-Labhart-Willi syndrome with central precocious puberty and empty sella syndrome. Acta Paediatr 1999;88:12957.

48. Naule L, Kaiser UB. Evolutionary conservation of MKRN3 and other makorins and their roles in puberty initiation and endocrine functions. Semin Reprod Med 2019;37:16673.

49. Hagen CP, Sorensen K, Mieritz MG, Johannsen TH, Almstrup K, Juul A. Circulating MKRN3 levels decline prior to pubertal onset and through puberty: a longitudinal study of healthy girls. J Clin Endocrinol Metab 2015;100:1920-6.

50. Dauber A, Cunha-Silva M, Macedo DB, Brito VN, Abreu AP, Roberts $S A$, et al. Paternally inherited DLK1 deletion associated with familial central precocious puberty. J Clin Endocrinol Metab 2017;102:1557-67.

51. Macedo DB, Kaiser UB. DLK1, notch signaling and the timing of puberty. Semin Reprod Med 2019;37:174-81.

52. Gomes LG, Cunha-Silva M, Crespo RP, Ramos CO, Montenegro LR, Canton A, et al. DLK1 is a novel link between reproduction and metabolism. J Clin Endocrinol Metab 2019;104:2112-20.

53. Montenegro L, Labarta JI, Piovesan M, Canton APM, Corripio $\mathrm{R}$, Soriano-Guillen $\mathrm{L}$, et al. Novel genetic and biochemical findings of DLK1 in children with central precocious puberty: a Brazilian-Spanish study. J Clin Endocrinol Metab 2020;105:dgaa461.

54. Lee HS, Kim KH, Hwang JS. Association study of DLK1 in girls with idiopathic central precocious puberty. J Pediatr Endocrinol Metab 2020 Jul 5 [Epub]. https://doi.org/10. 1515/jpem-2020-0014.

55. Chen T, Chen L, Wu H, Xie R, Wang F, Chen X, et al. Low frequency of MKRN3 and DLK1 variants in Chinese children with central precocious puberty. Int J Endocrinol 2019; 2019:9879367.

56. Persson-Augner D, Lee YW, Tovar S, Dieguez C, Meister B. Delta-like 1 homologue (DLK1) protein in neurons of the arcuate nucleus that control weight homeostasis and effect of fasting on hypothalamic DLK1 mRNA. Neuroendocrinology 2014;100:209-20.

57. Meister B, Perez-Manso M, Daraio T. Delta-like 1 homologue is a hypothalamus-enriched protein that is present in orexin-containing neurones of the lateral hypothalam- 
ic area. J Neuroendocrinol 2013;25:617-25.

58. Yevtodiyenko A, Schmidt JV. Dlk1 expression marks developing endothelium and sites of branching morphogenesis in the mouse embryo and placenta. Dev Dyn 2006;235: 1115-23.

59. Butler MG. Imprinting disorders in humans: a review. Curr Opin Pediatr 2020;32:719-29.

60 . Kotler J, Haig D. The tempo of human childhood: a maternal foot on the accelerator, a paternal foot on the brake. Evol Anthropol 2018;27:80-91.

61. Canton A, Krepischi A, Montenegro LR, Costa S, Rosenberg C, Steunou V, et al. Insights from the genetic characterization of central precocious puberty associated with multiple anomalies. Hum Reprod 2021;36:506-18.

62. Montgomery GW, Zondervan KT, Nyholt DR. The future for genetic studies in reproduction. Mol Hum Reprod 2014; 20:1-14.

63. Elks CE, Perry JR, Sulem P, Chasman DI, Franceschini N, $\mathrm{He} C$, et al. Thirty new loci for age at menarche identified by a meta-analysis of genome-wide association studies. Nat Genet 2010;42:1077-85.

64. Perry JR, Day F, Elks CE, Sulem P, Thompson DJ, Ferreira T, et al. Parent-of-origin-specific allelic associations among
106 genomic loci for age at menarche. Nature 2014;514: 92-7.

65. Dai YL, Fu JF, Liang L, Gong CX, Xiong F, Luo FH, et al. Association between obesity and sexual maturation in Chinese children: a muticenter study. Int J Obes (Lond) 2014; 38:1312-6.

66. Lee HS, Park HK, Kim KH, Ko JH, Kim YJ, Yi KH, et al. Estrogen receptor a gene analysis in girls with central precocious puberty. J Pediatr Endocrinol Metab 2013;26:645-9.

67. Lee HS, Kim YJ, Hwang JS. No effect of the estrogen receptor a gene polymorphisms in the etiology of precocious puberty in girls. Exp Clin Endocrinol Diabetes 2013; 121:206-9.

68. Jeong HR, Lee HS, Hwang JS. LHCGR gene analysis in girls with non-classic central precocious puberty. Exp Clin Endocrinol Diabetes 2019;127:234-9.

69. Lee HS, Kim KH, Hwang JS. Association of aromatase (TTTA)n repeat polymorphisms with central precocious puberty in girls. Clin Endocrinol (Oxf) 2014;81:395-400.

70. Grandone A, Capristo C, Cirillo G, Sasso M, Umano GR, Mariani M, et al. Molecular screening of MKRN3, DLK1, and KCNK9 genes in girls with idiopathic central precocious puberty. Horm Res Paediatr 2017;88:194-200. 